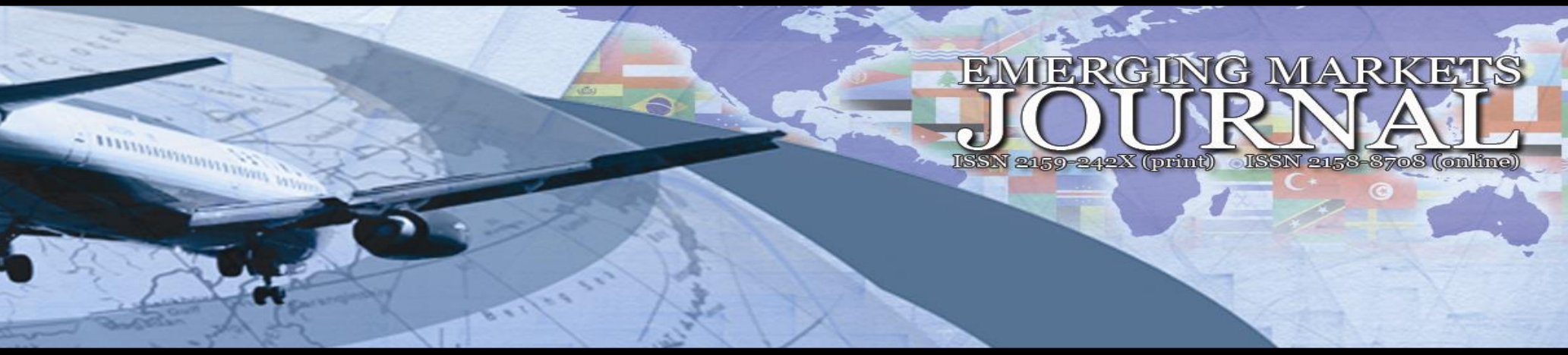

\title{
The Complexity of Relationship between Corporate Social Responsibility (CSR) and Financial Performance
}

\section{Golrida Karyawati P}

Brawijaya University, Indonesia | golridda@yahoo.com

\section{Bambang Subroto}

Brawijaya University, Indonesia | bambang@ub.ac.id

\section{Sutrisno T}

Brawijaya University, Indonesia | sutrisno@ub.ac.id

\section{Erwin Saraswati}

Brawijaya University, Indonesia | erwin_saraswati@yahoo.com

Volume 8 No 2 (2018) ｜ ISSN 2158-8708 (online) | DOI 10.5195/emaj.2018.155 | http://emaj.pitt.edu |

\begin{abstract}
This study argues that, inconsistent results of the Corporate Social Responsibility (CSR) relationship with financial performance is due to the complexity of relationship between two variables. The complexity of relationship stems from the nature of CSR, which is unseparable from its environment. This nature of relationship brings unfavourable impact on empirical research. The conclusion obtained from empirical evidents of such relationship will be highly contextual and lack generalization. This study proposes variables that led to the complexity of CSR relationship and financial performance, which are country characteristics as well as CSR forms and dimensions. Country characteristics determine the tendency of CSR practices, which finally influence the strength of CSR relationship with financial performance. The selection of CSR forms and dimensions to be done is part of a company's strategy in an effort to achieve legitimacy.
\end{abstract}

Keywords: CSR, Financial Performance, Country Characteristics, Form and Dimension of CSR

\section{(cc) BY}

New articles in this journal are licensed under a Creative Commons Attribution 3.0 United States License.

\section{UILIS D-Sente}

This journal is published by the University Library System of the University of Pittsburgh as part of its D-Scribe Digital Publishing Program, and is cosponsored by the University of Pittsburgh Press. 


\section{The Complexity of Relationship between Corporate Social Responsibility (CSR) and Financial Performance}

\author{
Golrida Karyawati P \\ Bambang Subroto \\ Sutrisno T \\ Erwin Saraswati
}

\section{Introduction}

This study arques that, the inconsistent results of previous studies on the relationship between Corporate Social Responsbility (CSR) and financial performance is stemmed from the complexity of the relationship, which cause limitations to the empirical research of such relationship (Macdonald \& Maher, 2013). Empirical research limitations on CSR relationship with financial performance even occurs on the conceptual level.

CSR is a concept with a wide and detailed nature (Valiente et al, 2012; Hutchins \& Sutherland, 2008; Jamali and Mirshak, 2007; Mehar and Rahat, 2007). The concept of CSR is even embedded with other concepts such as citizenship, ethics, sustainability, corporate governance, etc (Sprinkle \& Maines, 2010; Kang et al, 2010; Grosbois, 2012; Zheng et al, 2014; Weber, 2008; Taysir \& Pazarcik, 2013). This nature of CSP concept raises the operational and methodological differences on examining the relationship between CSR and financial performance (Aupperle et al., 1985; Griffin \& Mahon, 1997). In collecting CSR data, it is often difficult to determine whether a particular activity is included in the CSR definition or not. The wide and detailed nature of CSR concept on the other side, creates problems of measurement. Different CSRs may require different measurements. CSR studies tend to have conceptual and methodical social critics (Elsayed and Paton. 2005; Filbeck \& Gorman. 2004; Brammer and Millington. 2008). Testing the relationship between CSR and financial performance suffers from procedural and methodological limitations (Aupperle et al., 1985; Griffin \& Mahon, 1997).

On the practical level, CSR practices can not be separated from the environment, because CSR issues are basically environmental issues. Institutional characteristics such as economic condition, social issues, culture, law etc. determine the tendency and preference of companies in doing CSR. Institutional factors also influence forms and intensity of CSR practices. CSR practices are changing over time along with the changing environement. In the begining, CSR issues were only issues related to employees and firm owners. As the environment changed, new issues emerged and the issue of CSR became wider and detailed. Currently, the issues of corporate governance and environment have become more critical as well.

Therefore, empirical testing of CSR and financial performance generates contextual conclusions. It will be difficult to make a generalization on CSR research as explained by Griffin and Mahon (1997). CSR research nature is actually far from the ideal research (Macdonald \& Maher. 2013). The inconsistent results of previous studies on CSR and financial performance proves the imprefection of that kind of research. This study aims to disclose the complexity of the relationship between CSR and financial performance.

\section{CSR Relationship with Financial Perfomance}

Previous research on the relationship between CSR and financial performance showed inconsistent results. Among those research, some proved and indicated positive relationship between the two variables (Wang et al. 2011; Jo \& Harjoto, 2011; Mishra \& Suar, 2010; Cheung et al.2010; Rettab et al.2009; Sembiring, 2005; Goll \& Rasheed, 2004; Billings, 1999; McGuire et al. 1988). Analysis of the relationship between CSR and financial performance on different dimensions such as employees, customers, social issues, environment and suppliers showed a positive relationship between CSR and financial performance (Mishra \& Suar, 2010). Research also found out that, environment variables determine the relationship between CSR and financial performance (Goll \& Rasheed, 2004). Discretionary CSR environment enhances financial performance and vice versa.

However, some research found inconsistent relationship between CSR and financial performance (Aupperle et al. 1985; McGuire et al., 1988; McWilliam \& Siegel, 2000; Seifert et al. 2003; Brammer et al., 2006; Mehar \& Rahat, 2007; Chih et al.2010). Empirical evidence of the previous reserach indicated a non-linear relationship between CSR and financial performance. Brammer \& Millington (2008) and Barnett \& Salomon (2006) for example, found that, the relationship between CSR and financial performance varies according to disclosure of CSR intensity. On low and high level CSR disclosure enhancing financial performance, low level CSR enhances short term financial performance, and high level CSR enhances long term financial performance.

Inconsistent results of previous studies analyzing the relationship between CSR and financial performance, critisize the work of stakeholder and legitimacy theories in explaining CSR relationship with financial performance. Stakeholder and legitimacy theories suggest that, the relationship between CSR and financial performance is positive. However, testing the relationship between CSR and financial performance using stakeholder and legitimacy theories is oversimplifying the relationship and ignoring the complexity of the relationship that generates very contextual conclusions. Analyzing CSR relationship with financial perfomance should include institutional characteristics, which influence CSR practices.

Country characteristics also determine the tendency of CSR practices (Falck \& Heblich, 2007). 
Previous research generally classify CSR practices under developed and developing countries. CSR practices in developing countries to some extent are different from CSR practices in developed countries (Beddewala \& Herzig, 2012; Welford R, 2004; Baughn et al, 2007). Economic development influences CSR practices as well. Companies in developed countries do more CSR practices than companies in developing countries (Baughn et al, 2007). Many developing countries are rich of natural resources, but because of weak terms of corporate governance, CSR practice is even proving what is called resource curse, instead of providing benefits (Wiig \& Koldtad, 2010). So far, analysis about CSR relationship with financial performance are done more in developed countries than in developing countries (Rettab et al, 2009).

Motivation of doing CSR practices influences companies in selecting forms and dimensions of CSR that will be done. Companies in Asia and developing countries tend to engage in philanthropic activities compared to companies in developed countries (Beddewela \& Herzig, 2013; Jamali \& Mirshak, 2007). Zheng et al (2014) stated that, philanthropic actions are expected to gain external legitimacy, while CSR sustainability is generally expected to gain internal legitimacy. Therefore, company's preference for CSR forms and dimensions carried out describes the company's strategy.

\section{The Relationship of CSR and Financial Perfomance}

Stakeholder Theory (Freeman, 2001) and Legitimacy Theory (Zheng et al, 2014; Tilling, 2004; Suchman, 1995) indicate that, CSR generates benefit for the company. Stakeholder Theory explains the certainty relationship of a company and its stakeholders. As a consequence, companies should maintain their relationship with stakeholders for the continuity of their business. CSR is considered as an important tool in maintaining the relationship with stakeholders (Jones, 1995).

Legitimacy theory requires companies to be legitimate for keeping their business, enabling continuity and securing the organization from external or internal threats. Companies with higher legitimacy get access to varies resources easier, which bring benefit to the organization. Internal legitimacy encourages employees' performance, which finally enhances financial performance (Wang et al, 2011; Harjoto \& Jo, 2011; Mishra \& Suar, 2010; Cheung et al, 2010; Rettab et al, 2009; Sembiring, 2005; Goll \& Rasheed, 2004 ; William \& Siegel, 2001; Billings, 1999; McGuire et al, 1988). The inconsistent findings of CSR and financial relationship is due to the complexity of the relationship (Valiente et al, 2012; Hutchins \& Sutherland, 2008; Jamali \& Mirshak, 2007). CSR practices are related to social issues as well (Husted. 2000), which are very dinamic.

Fiori (2007) summarized that, the increasing attention towards CSR begins with the awareness that, CSR practices will enhance a company's performance. Stakeholder theory perceives that, stakeholder fulfillment expectation improves financial performance (Porter \&
Van der Linde, 1995). Stanwick (1998) and Verschoor (1998) emphasized that, good CSR will simplify the relationship between company and its stakeholders. According to the instrument theory, CSR issues can be managed to generate profit for company (Jones, 1995). If a company communicates its CSR practices well which satisfy the stakeholder needs, it can affect financial perfomance for the organization (Rettab, 2009).

Even though a company may spend a lot of resourcess to execute CSR, according to Williams \& Siegel, (2001), market equality will work to compensate the cost of CSR activities with profit. However, some CSR activities require too much resources in a way that can worse a company's competition (Friedman, 1970). In that case, CSR behavior may generate negative relationships with financial performance, since it violates againts company's value maximization due to social constraints (Jensen, 2001). Negative relationship can also occur when a manager misuses CSR discretionary to fulfill his or her interest, instead of considering shareholders or other parties (Williamson, 1964; Jensen \& Meckling, 1976).

Husted and Allen (2009) argued that, the relationship between CSR and financial performance is positive as long as CSR is directed on value creation drivers. Husted \& Allen (2009) also identified ways to manage CSR for value cretion drivers which are centrality, visibility, and voluntarism. Company's ability to manage CSR determines its effectivity in influencing financial performance. CSR will generate financial performance if it is managed in an appropriate way.

\section{Country Characteristic on the Relationship of CSR and Financial Perfomance}

Stakeholder and legitimacy theories indicate a positive relationship between CSR and financial performance. However, both theories are absent in explaining the complex process of CSR in influencing financial performance, so that the inconsistent results of CSR relationship with financial performance examination can be explained. Institutional theory explains the process of CSR in influencing financial performance along with institutional factors. Previous reseachers have recognized institutional influence on CSR practices at the country level (Husted \& Allen, 2006; Baughn et al, 2007). Husted \& Allen (2006) recognized that, institutional pressure takes more important role in CSR decision making than strategic related social and stakeholder issues. Wiig \& Koldstat (2010) indicated that, institutional factors determine the effectivity of CSR practice as a company strategy.

The strength of CSR relationship with financial performance is influenced by a country's institutional factors ( $\mathrm{Li}$ et al, 2010; Griffin \& Mahon, 1997). Countries which have similarity in terms of institutional characteristics tend to have a lot of similarity in CSR practices. Generally, analysis of CSR practices on the country level refers to institutional characteristics.

Previous researchers did tend to classify CSR practices based on developing and developed countries characteristics (Beddewela \& Herzig, 2013; Jamali \& Mirshak, 2007; Baughn et al, 2007; Chapple \& Moon, 
2005; Ewing \& Windisch, 2007; Kimber \& Lipton, 2005 ; de Oliviera, 2006; Qu, 2007; Roper \& Weymes, 2007; Welford, 2004), because grouping countries under specific classifications results similarity in terms of analyzing CSR practices (Baughn et al, 2007). Firstly, economic conditions is important in understanding CSR practices. On the country level, CSR practices are influenced by economic development (Baughn et al, 2007). Resource base view states that, CSR practices depend upon a company's resources, since the cost of CSR commitment in many cases is high. Generally, economic conditions of developed countries are better than developing countries. Previous research on CSR practices on the country level prove that, CSR practices in developing countries tend to be lower than those in developed countries (Welford, 2004), because economic development in those countries is lower than in developed countries (Baughn et al, 2007).

Secondly, governance of developing countries is generally weaker than developed countries (Beddewela \& Herzig, 2013; Jamali \& Mirshak, 2007). Institutional legal framework of developing countries that have not yet well developed, weakens companies' efforts in doing CSR practices (Rettab et al., 2009). Beddewela \& Herzig (2013) found what is called "duality" on Multination Corporations (MNCs) in developing countries, which is the contradiction between the government institution of the host (parent) company and the government institution of the country where the subsidiary operates. Institutional Duality causes differences in CSR practices between two countries.

Thirdly, CSR practices on the country level is also influenced by culture, social issues and politics (Gerson, 2007). Differences in culture and other social contexts explain differences in CSR practices (Halme \& Laurila, 2009; Midttun et al, 2006). Many companies in developing countries lack awareness of good communication of CSR to stakeholders (Rettab et al. 2009), due to cultural, social and political issues.

\section{Forms and Dimensions Variation of CSR}

Halme \& Laurila, (2009); Zheng et al, (2014) emphasized that, a company's decision concerned with the forms and dimensions of CSR to be exercised is part of the company's strategy. Orlitzky et al. (2003) argued that, the effectiveness of CSR in improving financial performance also depends on how a company is managing its CSR initiatives. The CSR management strategy in finding the best way to implement CSR should also be mentioned at this point. How the CSR is planned and carried out also affects the expected outcomes such as financial performance (Halme \& Laurila, 2009; Porter \& Kramer, 2006).

Branco \& Rodrigues, (2006); McWilliams et al, (2006), Porter \& Kramer (2006), Donaldson \& Preston, (1995) argued that, CSR is the source of competitive advantage if it is integrated with a company's strategy. Part of CSR strategy is to determine the forms and dimensions of CSR in an effort to achieve legitimacy. Issues about CSR forms have attracted the attention of researchers (Halme \& Laurila, 2009; Porter \& Kramer, 2006). Halme \& Laurila (2009) suggested that, CSR should be integrated with the core business to enhance financial performance.

Companies tend to adjust their CSR activities with contemporary issues. Currently, issues such as employement, environment and society are still attracting the attention of stakeholders. Many studies were run analyzing these issues and dimensions by Affif \& Ananta (2013); Fiori et al (2007); Uadiale \& Fagbeni (2012); and Brammer et al, (2006).

Other issues such as product, diversity and corporate governance are becoming more important as found out by Inoue \& Lee (2012), Schreck (2011) and Michelon et al (2013). However, the attention towards CSR issues varies around the world. According to Visser (2009), CSR issues on economic dimension tend to occur in developing countries, since many developing countries are still having economic and poverty problems. On the other side, developing countries lack interest on CSR dimension of law.

Previous research also found significant relationship between philanthtopy and company's reputation (Brammer \& Millington, 2005). Philanthropy affects the perception towards varying stakeholders such as investors, customers, suppliers, employees and other stakeholders (Saiia, et al, 2003; Smith, 1994). Building public perception is increasingly important in condition, where stakeholders are getting stronger. Philanthropic activities are more easily seen by stakeholders compared to other forms of CSR activities, thus easier to build positive perceptions and gain a positive reputation in the eyes of stakeholders. Literature on reputation show the relationship between company reputation and CSR (Fryxell \& Wang, 1994; McGuire et al, 1988).

According to Halme \& Laurila (2009), philanthropy activities generate social outcome more than other CSR acitvities. Wang \& Qian (2011) analyzed the effect of philanthropy on company'performance in various conditions, and suggested that companies adopt philanthropy, because it made easier for companies to get socio-political legitimacy that brought positive stakeholder responses and facilitated political access.

Zheng et al. (2014) found out that, companies prefer philanthropy activities for the purpose of external legitimation. Through philanthropy activities, stakeholder trust can be achieved which will let the company to get easier access to the resources needed, alleviate business risks, reduce transaction costs (Hillman \& Keim, 2001; Jones, 1995; Wang et al, 2008) and finaly enhance the company's performance. However, it is still a debate whether philanthropy activities contribute to financial performance (Orlitzkye et al, 2003; Saiia et al, 2003; Seifert et al, 2004). Muller \& Kraussl (2011) argued that, stakeholders response on philanthropy is dependent on how they perceive genuity of the philanthropy action.

Philanthropy activities are expected to provide tangible benefits, if philanthropy strategy is connected to a whole business purpose (Muller \& Kraussl, 2011; Hess et al, 2002; Porter \& Kramer, 2002). However, philanthropy activities will negatively affect financial performance if it is perceived as a blunt effort (Godfrey, 
2005). In return, philanthropy will positively affect financial performance if it is perceived sincere (Dean, 2003).

\section{Conclusion}

CSR improves financial performance, but the analysis of relationship between CSR and financial performance must also consider variables that affect the relationship between CSR and financial performance, including country characteristics as well as forms and dimensions of CSR. Future research should find and consider other variables in CSR relations with financial performance by expanding the analysis of institutional factors

\section{References}

Afiff, S \& Anantadjaya,S.P.D. 2013. CSR \& Performance: Any Evidence from Indonesian LQ45?, Review of Integrative Business \& Economics Research, 2 (1), 85-101.

Aupperle, K.E, Carroll, A.B, \& Hatfield J.D. 1985. An Empirical Examination of The Relationship Between Corporate Social Responsibility and Profitability, The Academy of Management Journal, 28 (2), 446-463.

Barnett, M.L. \& Salomon, R.M. 2006. Beyond Dichotomy: The Curvilinear Relationship Between Social Responsibility dan Financial Performance, Strategic Management Journal, 27 (1), 1101-1122.

Baughn, C, Bodie.N \& McIntosh. 2007. Corporate Social and Environmental Responsibility in Asian Countries and Other Geographical Regions, Corporate Social Responsibility and Environmental Management, 14 (4), 189-205.

Beddewela, E. \& Herzig, C. 2013. Corporate Social Reporting by MNCs' Subsidiaries in Sri Lanka, Accounting Forum, 37, 135-149.

Billings, B.K. 1999. Revisiting The Relation Between The Default Risk of Debt dan The Earnings Response Coefficient, The Accounting Review, 74 (4), 509-522.

Brammer, S \& Millington, A. 2008. Does It Pay to Be Different? An Analysis of The Relationship Between Corporate Social and Financial Performance, Strategic Management Journal, 29 (12), 1325-1343.

Brammer, S, Brooks, C \& Pavelin, S. 2006. Corporate Social Performance and Stock Returns: UK Evidence from Disaggregate Measures, Financial Management, 35 (3), 97-116.

Brammer, S \& Millington, A. 2005. Corporate Reputation and Philanthropy: An Empirical Analysis, Journal of Business Ethics, 61, 29-44.

Branco, M.C \& Rodrigues, L.L. 2006. Corporate Social Responsibility and Resource-Based Perspectives, Journal of Business Ethics, 69 (2), 111-132.
Chapple, W \& Moon, J. 2005. Corporate Social Responsibility (CSR) in Asia: A Seven Country Study of CSR Website Reporting, Business and Society, 44 (4), 415-441.

Cheung, Y.L, Tan, W, Ahn, H.J \& Zhang, Z. 2010. Does Corporate Social Responsibility Matter in Asian Emerging Markets?, Journal of Business Ethics, 92 (3), 401-413.

Chih, H.L, Chih, H.H, \& Chen, T.Y. 2010. On The Determinants of Corporate Social Responsibility: International Evidence on The Financial Industry, Journal of Business Ethics, 93 (1), 115-135.

Dean, D. 2003. Consumer Perceptions of Corporate Donations: Effects of Company Reputationfor Social Responsibility and Type of Donation, Journal of Advertising, 32 (4), 91-102.

DeOliveira, J.A.P. 2006. Corporate Citizenship in Latin America: New Challenges for Business, The Journal of Corporate Citizenship, 21, 17-20.

Donaldson, T \& Preston, L.E. 1995. The Stakeholder Theory of The Corporation: Concepts, Evidence, and Implications, The Academy of Management Review, 20 (1), 65-91.

Elsayed, K \& Paton, D. 2005. The Impact of Environmental Performance on Firm Performance: Static and Dynamic Panel Data Evidence, Structural Change and Economic Dynamics, 16 (2005), 395-412.

Ewing, M.T. \& Windisch, L.E. 2007. Contemporary Corporate Social Responsibility in China: An Extension of Confucian Philosophy?, Asian Business and Economics Research Unit Discussion Paper 44, Monash University.

Falck, O \& Heblich, S. 2007. Corporate Social Responsibility: Doing Well by Doing Good, Business Horizons, 50, 247-254.

Filbeck, G \& Gorman, R.F. 2004. The Relationship Between The Environmental and Financial Performance of Public Utilities, Environmental and Resource Economics, 29, 137-157.

Fiori, G, Donato, F.D.D \& Izzo, M.F. 2007. Corporate Social Rersponsibility and Firms Perfomance An Analysis on Italian Listed Companies, http://ssrn.com/abstract=1032851.

Freeman, R. 2001. A Stakeholder Theory of The Modern Corporation, Perspectives in Business Ethics, 3 (144), 38-48.

Friedman, M. 1970, September 13. The Social Responsibility of Business Is to Increase Its Profi ts, New York Times Magazine.

Fryxell, G.E. \& Wang, J. 1994. The Fortune Corporation Reputation Index: Reputation for What?, Journal of Management, 20 (1), 1-14. 
Gerson, B. 2007. CSR Best Practices, China Business Review, May-June, 20-25.

Godfrey. P.C. 2005. The Relationship Between Corporate Philanthropy and Shareholder Wealth: a Risk Management Perspective, Academy of Management Review, 30 (4), 777-798.

Goll, I \& Rasheed, A.A. 2004. The Moderating Effect of Environmental Munificence and Dynamism on The Relationship Between Discretionary Social Responsibility and Firm Performance, Journal of Business Ethics, 49 (1), 41-54.

Griffin, J.J \& Mahon, J.F. 1997. The Corporate Social Performance and Corporate Financial Performance Debate, Business and Society, 36 (1), 5-31.

Grosbois, D.D. 2012. Corporate Social Responsibility Reporting by The Global Hotel Industry: Commitment, Initiatives and Performance, International Journal of Hospitality Management, 31, 896-905.

Halme, M \& Laurila, J. 2009. Philanthropy, Integration or Innovation? Exploring The Financial and Societal Outcomes of Different Types of Corporate Responsibility, Journal of Business Ethics, 84 (3), 325-339.

Harjoto, M \& Jo, H. 2011. Corporate Governance and CSR Nexus, Journal of Business Ethics, 100, 4567.

Hess, D, Rogovsky, N \& Dunfee, T. 2002. The Next Wave of Corporate Community Involvement: Corporate Social Initiatives, California Management Review, 44 (2), 110-125.

Hillman, A.J \& Keim, G.D. 2001. Shareholder Value, Stakeholder Management, and Social Issues: What's The Bottom Line? Strategic Management Journal, 22 (2), 125-139.

Husted, B.W \& Allen, D.B. 2009. Strategic Corporate Social Responsibility and Value Creation: A Study of Multinational Enterprises in Mexico, Management International Review, 49 (6), 781799.

Husted, B.W \& Allen, D.B. 2006. Corporate Social Responsibility in The Multinational Enterprise: Strategic and Institutional Approaches, Journal of International Business Studies, 37 (6), 838849.

Husted, Bryan W. 2000, A contingency theory of corporate social performance, Business and Society, 39 (1), 24-48.

Hutchins, M.J \& Sutherland, J.W. 2008. An Exploration of Measures of Social Sustainability and Their Application to Supply Chain Decisions, Journal of Cleaner Production, 16, 1688-1698.
Inoue, Y \& Lee, S. 2012. Effects of Different Dimensions of Corporate Social Responsibility on Corporate Financial Performance in TourismRelated Industries, Tourism Management, 32 (2011), 790-804.

Jamali, D, Safieddine, A.M \& Rabbath, M. 2008. Corporate Governance and Corporate Social Responsibility Synergies and Interrelationships, Corporate Governance, 16 (5), 443-459.

Jamali, D \& Mirshak, R. 2007. Corporate Social Responsibility (CSR): Theory and Practice in a Developing Country Context, Journal of Business Ethics, 72 (3), 243-262.

Jensen, M.C. 2001. Value Maximisation, Stakeholder Theory, and Corporate Objective Function, European Financial Management, 7 (3), 297317.

Jensen \& Meckling 1976. Theory of The Firm: Managerial Behaviour, Agency Costs and Ownership Structure, Journal of Financial Economics, 3 (4), 305-360.

Jo, H \& Harjoto, M.A. 2011. Corporate Governance and Firm Value: The Impact of Corporate Social Responsibility, Journal of Business Ethics, 103 (3), 351-383.

Jones, T. 1995. Instrumental Stakeholder Theory: A Synthesis of Ethics and Economics, Academy of Management Review, 20, 404-437.

Kang, K.H, Lee, S \& Huh, C. 2010. Impacts of Positive and Negative Corporate Social Responsibility Activities on Company Performance in The Hospitality Industry, International Journal of Hospitality Management, 29, 72-82.

Kimber, D \& Lipton, P. 2005. Corporate Governance and Business Ethics in The Asia-Pacific Region, Business \& Society, 44 (2), 178-210.

Li, S, Fetscherin, M, Alon, I, Lattemann, C \& Yeh, K. 2010. Corporate Social Responsibility in Emerging Markets: The Importance of The Governance Environment, Management International Review, 50 (5), 635-654.

Macdonald, J.B. \& Maher, M. 2013. The Relationship Between Equity Dependence and Environmental Performance, Journal of Leadership, Accountability and Ethics, 10 (2), 35-45.

McGuire, J.B, Sundgren, A. \& Schneeweis, T. 1988. Corporate Social Responsibility and Firm Financial Performance, The Academy of Management Journal, 31 (4), 854-872.

McWilliams, A, Siegel, D.S \& Wright, P.M. 2006. Corporate Social Responsibility:Strategic Implications. Journal of Management Studies, 43 (1), 1-18. 
McWilliams, A \& Siegel, D. 2001. Corporate Social Responsibility: A Theory of The Firm Perspective, The Academy of Management Review, 26 (1), 117-127.

McWilliams, A \& Siegel, D. 2000. Corporate Social Responsibility and Financial Performance: Correlation or Misspecification? Strategic Management Journal, 21 (5), 603-609.

Mehar, A \& Rahat, F. 2007. Impact of Corporate Social Responsibility on Firm's Financial Performance, South Asian Journal of Management Sciences, 1 (1), 16-24.

Michelon, G, Boesso, G \& Kumar, K. 2013. Examining The Link Between Strategic Corporate Social Responsibility and Company Performance: An Analysis of The Best Corporate Citizens, Corporate Social Responsibility Environmental Management, 20, 81-94.

Midttun, A, Gautesen, K \& Gjølberg, M. 2006. The Political Economy of CSR in Western Europe, Corporate Governance International Journal of Business in Society, 6 (4), 369-385.

Mishra, S \& Suar, D. 2010. Does Corporate Social Responsibility Influence Firm Performance of Indian Companies?, Journal of Business Ethics, 95 (4), 571-601.

Muller, A \& Kräussl, R. 2011. The Value of Corporate Philanthropy During Times of Crisis: The Sensegiving Effect of Employee Involvement, Journal of Business Ethics, 103 (2), 203-220.

Orlitzky, M, Schmidt, F.L \& Rynes, S.L. 2003. Corporate Social and Financial Performance: A Meta-analysis, Organization Studies, 24 (3), 403441.

Porter, M. \& Kramer, M. 2006. Strategy and Society: The Link Between Competitive Advantage and Corporate Social Responsibility, Harvard Business Review, 85 (12), 1-14.

Porter, M. \& Kramer, M. 2002. The Competitive Advantage of Corporate Philanthropy, Harvard Business Review, 80, 56-68.

Porter, M.E \& Linde, C.V.D. 1995. Toward a New Conception of The EnvironmentCompetitiveness Relationship, The Journal of Economic Perspectives, 9 (4), 97-118.

Qu, R. 2007. Corporate Social Responsibility in China: Impact of regulations, Market Orientation and Ownership Structure, Chinese Management Studies, 1 (3), 198-207.

Rettab, B, Brik, A.B \& Mellahi, K. 2009. A Study of Management Perceptions of The Impact of Corporate Social Responsibility on Organisational Performance in Emerging Economies: The Case of Dubai, Journal of Business Ethics, 89 (3), 371-390.
Roper, J. \& Weymes, E. 2007. Reinstating The Collective: A Confucian Approach to Well-Being and Social Capital Development in a Globalised Economy, Journal of Corporate Citizenship, 26, 135-144.

Saiia, D.H, Carroll, A.B \& Buchholtz, A.K.. 2003. Philanthropy as Strategy: When Corporate Charity Begins at Home, Business \& Society, 42 (2), 169-201.

Schreck, P. 2011. Reviewing The Business Case for Corporate Social Responsibility: New Evidence and Analysis, Journal of Business Ethics, 103 ( 2), 167-188.

Seifert, B, Morris, S.A \& Bartkus, B.R. 2004. Having, Giving, and Getting:Slack Resources, Corporate Philanthropy,and Firm Financial Performance, Business \& Society, 43 (2), 135-161.

Seifert, B, Morris, S.A \& Bartkus, B.R. 2003. Comparing Big Givers and Small Givers: Financial Correlates of Corporate Philanthropy, Journal of Business Ethics, 45 (3), 195-211.

Sembiring, E.R. 2005. Karakteristik Perusahaan dan Pengungkapan Tanggung Jawab Sosial: Study Empiris pada Perusahaan yang Tercatat di Bursa Efek Jakarta, Prosiding SNA VIII, 379-395.

Smith, C.N. 1994. The New Corporate Philanthropy, Harvard Business Review, 72 (3), 105-116.

Sprinkle, G.B. \& Maines, L.A. 2010. The Benefits and Costs of Corporate Social Responsibility, Business Horizons, 53, 445-453.

Stanwick, P.A. \& Stanwick, S.D. 1998. The Relationship Between Corporate Social Performance, and Organizational Size, Financial Performance, and Environmental Performance: An Empirical Examination, Journal of Business Ethics, 17, 195-204.

Suchman, M.C. 1995. Managing Legitimacy: Strategic and Institutional Approaches, Academy of Management Review, 20, 571-610.

Taysir, E.A \& Pazarcik, Y. 2013. Business Ethics, Social Responsibility and Corporate Governance: Does The Strategic Management Field Really Care About These Concepts?, Procedia - Social and Behavioral Sciences, 99, 294-303.

Tilling, M. 2004. Communication at The Edge: Voluntary Social and Environmental Reporting in The Annual Report of a Legitimacy Threatened Corporation. APIRA Conference Proceedings.

Uadiale, O.M \& Fagbemi, T.O. 2012. Corporate Social Responsibility and Financial Performance in Developing Economies: The Nigerian Experience, Journal of Economics and Sustainable Development, 3 (4), 44-55. 
Valiente, J.M.A, Ayerbe, C.G \& Figueras, M.S. 2012. Social Responsibility Practices and Evaluation of Corporate Social Performance, Journal of Cleaner Production, 35, 25-38.

Verschoor, C.C. 1998. A Study of The Link Between as Corporation's Financial Performance and Its Commitment to Ethics, Journal of Business Ethics, 17, 1509-1516.

Visser, W. 2009. Corporate Social Responsibility in Developing Countries, https://www.researchgate.net/publication/285925 758.

Wang, H. \& Qian, C. 2011. Corporate Philanthropy and Corporate Financial Performance: The Roles of Stakeholder Response and Political Access, Academy of Management Journal, 54 (6), 11591181.

Wang, H, Choi, J \& Li, J. 2008. Too Little or Too Much? Untangling The Relationship Between Corporate Philanthropy and Firm Financial Performance, Organization Science, (1), 143159.

Wang, M, Qiu, C \& Kong, D. 2011. Corporate Social Responsibility, Investor Behaviors, and Stock Market Returns: Evidence from Natural Experiment in China, Journal of Business Ethics, 101 (1), 127-141.

Weber, M. 2008. The Business Case for Corporate Social Responsibility: A Company-Level Measurement Approach for CSR, European Management Journal, 26, 247-261.

Welford, R. 2004. Corporate Social Responsibility in Europe and Asia: Critical Elements and Best Practice, Journal of Corporate Citizenship, 13 (1), 31-47.

Wiig, A. \& Kolstad, I. 2010. Multinational Corporations and Host Country Institutions: A Case Study of CSR Activities in Angola, International Business Review, 19 (2), 178-190.

Williamson, O.E. 1964. The Economics of Discretionary Behavior: Managerial Objectives in a Theory of The Firm, New York: Prentice-Hall.

Zheng, Q, Luo, Y \& Maksimov, V. 2014. Achieving Legitimacy Through Corporate Social Responsibility: The Case of Emerging Economy Firms, Journal of World Business, 687, 1-15. 